\title{
The Relationship between Commitment to the Organization, Perceived Organizational Support, Job Satisfaction, and Organizational Citizenship Behavior of Teachers
}

\author{
Rachel Holsblat ${ }^{*}$ \\ Talpiot College, Yotvata 3, Holon \\ *Corresponding author: rachelhol@walla.co.il
}

\begin{abstract}
Received October 30, 2014; Revised November 24, 2014; Accepted December 04, 2014
Abstract The study examines the relationship between teachers' organizational citizenship behavior (OCB) and their attitudes to work, including commitment to the organization, affective commitment and value congruence commitment, perceived organizational support and job satisfaction. The data were collected through the use of a questionnaire, distributed to a sample of 314 elementary school teachers from the center of Israel. The results of the study, obtained through Pearson correlations and multiple regressions, indicate that organizational citizenship behavior is a multidimensional variable directed to different parties in the school - students, teachers, and the organization. In addition, all the variables examined have a significant positive correlation with the teacher's behavior. The variable with the most significant correlation is commitment to the organization, which derives from the congruence between the values of the individual and the organization. The findings of the present study have theoretical and applied value for educators and educational policy makers.
\end{abstract}

Keywords: OCB, organizational commitment, perceived organizational support, satisfaction

Cite This Article: Rachel Holsblat, "The Relationship between Commitment to the Organization, Perceived Organizational Support, Job Satisfaction, and Organizational Citizenship Behavior of Teachers.” American Journal of Educational Research, vol. 2, no. 12 (2014): 1175-1181. doi: 10.12691/education-2-12-7.

\section{Introduction}

In the spirit of the reforms that are sweeping through the Western world in the post-modern era, educational systems are required to cope with far-reaching changes. In Israel, for example, the educational system has been trying to close wide economic, social and educational gaps [1,2]. To meet these challenges, school systems need teachers who are willing to invest time and effort in the school, above and beyond the formal requirements of their roles, and display behavior that is known as organizational citizenship behavior (OCB) [3,4]. In the literature on organizations, this behavior refers to extra-role behavior that goes beyond the worker's duty, and is not formally recognized by the organization's rewards system but contributes to the effectiveness of the organization $[5,6]$. The school, like other organizations, stands to benefit from the contributions of teachers who display high organizational citizenship behavior. For example, it has been shown that schools with a high rate of teacher OCB have a higher level of student achievement and a more pleasant school climate $[3,4]$.

OCB has been extensively researched in the past three decades among employees in different fields because of its contribution to the success of organizations. However, only a few studies have examined OCB among teachers, despite its positive impact on the effectiveness of schools $[3,7]$. Previous studies have found that attitudes influence the performance of OCB. Therefore, it is recommended to continue to investigate the phenomenon so as to reveal additional factors that have an influence on OCB [8,9].

The primary objective of the present study is to examine the concept of OCB in an educational setting in order to gain a better understanding of OCB. Specifically, this study examines the relationship between OCB and teacher attitudes, such as the teacher's commitment to the school (affective commitment and value congruence commitment), perceived organizational support (POS), and job satisfaction. Schools can derive considerable benefit from better understanding this behavior and its causes, so as to encourage a higher level of organizational citizenship behavior among teachers and increase school effectiveness [10].

\section{Conceptual Framework and Research Hypotheses}

\subsection{OCB: Background and Definitions}

The phenomenon of organizational citizenship behavior was first defined in the 1980s [11,12], and since then it 
has been the focus of considerable interest among different researchers. This concept represents an individual's actions that are neither officially part of the worker's role nor formally recognized by the organization's reward system, but they nevertheless promote organizational effectiveness [5,13].

Researchers explain that successful organizations need employees who go beyond their formal job responsibilities and freely give of their time and energy to succeed at the task at hand. Such altruism is not required by the job; yet it not only contributes to but is even critical for the smooth functioning of the organization and its effectiveness [14]. Previous research has shown that OCB significantly contributes to the functioning and success of a school. This behavior, which is not defined in the teachers' formal work agreements, can be directed to different factors in the school. OCB includes, for example, the help for students after school hours, adjustment of the learning to different levels of students, volunteering to prepare materials for and participate in extracurricular activities, cooperative work with and help for other teachers, making suggestions to improve the school, and volunteering for different committees. These actions are related to the technical core of the organization and they enable the schools to survive over time, to alleviate tension, and to increase the school effectiveness However, there is little research focusing on teachers and OCB, and thus there is no clear picture of the phenomenon [15,16,17].

Research has found that OCB is considered as a multidimensional concept, although there is no consensus regarding how many different dimensions there are and which they are $[18,19]$. The present study examines teachers' OCB according to the following three dimensions found by recent research conducted in Israeli schools [16,20,21]: (1) behavior directed to the students, such as teachers' supporting students who have difficulties after school; (2) behavior directed to other teachers, such as teachers helping new teachers; and (3) behavior directed to the school as an organization, such as teachers offering ideas for improving the school's image.

\subsection{Relationship between Attitudes and OCB}

Previous studies have found a relationship between worker attitudes and OCB [20,22]. Social exchange theory is used to explain how such attitudes influence OCB. According to this theory [23] which is based on the norm of reciprocity [24], there is a system of social exchange between the worker and the organization that results in OCB as one of its positive outcomes. Workers exhibit this behavior as a reward for the organization and certain people therein, in return for their support and assistance $[13,25]$. In other words, when the worker develops a positive attitude toward his work, he feels committed to 'pay' the organization back and will have more motivation in terms of OCB.

The present study focuses on three main variables of attitudes related to worker OCB that have been examined very little, if at all, among teachers: commitment to the organization, perceived organizational support, and job satisfaction.

\subsection{Organizational Commitment and OCB}

Organizational commitment is defined as the individual's loyalty to or relationship with the organization that employs him [26]. Previous research has found that organizational commitment is a multifaceted concept. Every form of commitment leads to different organizational outcomes [27].

The present study examines two forms of organizational commitment. Affective commitment, or loyalty, is an emotional response of attachment to and identification with the organization, which can be expressed in the worker's sense of belonging to the organization. The commitment creates an emotional attachment to the organization so that the individual who is strongly committed identifies with the organization, is involved in it, and enjoys the society therein [27]. Value congruence commitment refers to the worker's internalization or involvement with the organization, based on congruence between individual and organizational values [28].

Commitment develops on the basis of psychologically rewarding experiences [29]. Through the process of social exchange, as a result of the worker's positive experiences at work (whether due to his enjoyment or to his identification with the organization's values), he feels a commitment to his work. As a result, there is an increase in the worker's motivation and desire to contribute and do more than is expected of him, to promote the success and goals of the organization [30].

Previous research that found a positive correlation between commitment to the organization and teacher OCB did not investigate the specific dimensions of commitment addressed in the present study [8,31].

In the present research it is assumed that a high level of each one of the dimensions of commitment to the organization will lead to a high OCB in its different dimensions.

Hypothesis 1: A positive correlation will be found between affective commitment and OCB to the teachers, the organization, and the student.

Hypothesis 2: A positive correlation will be found between value congruence commitment and OCB to the teachers, the organization, and the student.

\subsection{Perceived Organizational Support (POS) and OCB}

Organizational support refers to any action adopted by the organization or its representatives that indicates concern for the workers' welfare. POS is the worker's general perception of the way in which the organization appreciates his contribution, is committed to him, and sees to his wellbeing; for example, the worker feels that the organization will be on his side in the case of personal problems [23]. Researchers [32] explain according to social exchange theories that when workers feel a high degree of support by the organization, they will feel a commitment to reward the organization with their loyalty and positive behaviors. Previous studies showed that POS was related to the performance of positive behaviors in the organization and to OCB [23].

From a review of the literature it appears that this variable has not been examined among teachers. The present study assumes that a positive correlation will be found between the teachers' OCB in its different 
dimensions and teachers who perceive the school as a supportive place.

Hypothesis 3: A positive correlation will be found between the teacher's perception of organizational support (POS) and the OCB to the teacher's organization and the student.

\subsection{Satisfaction in the Organization and OCB}

Satisfaction with the job, a variable that has been extensively studied, was found to be related to OCB performances in different organizations [19,31]. The concept of job satisfaction is based on Needs Theory, according to which the fulfillment of the individual's basic needs can contribute to satisfaction [33]. In other words, when a person is more satisfied at work, he is interested in retaining and strengthening his position. Therefore, his motivation to act with OCB is higher. An additional explanation for the connection between the variables is taken from Satisfaction Theory [34], which is based on the assumption that satisfaction is the result of the rewards which the individual perceives as positive. When the worker feels that he is receiving these rewards, he is satisfied and willing to do beyond his formal duties in the organization.

The present study adds to the little research that has been conducted on job satisfaction in schools [21,35] and assumes that teachers with considerable satisfaction in school will behave with more OCB to the different parties in the school.

Hypothesis 4: A positive correlation will be found between job satisfaction and OCB to the teachers, the organization, and the student.

\section{Method}

\subsection{Sample and Procedure}

The research sample included 314 teachers from sixteen public elementary schools in the center of Israel. As the majority of Israeli elementary school teachers are female, the participants in the study were mostly women (95\%), who had tenure in the educational system (84\%) and who taught full-time (80\%). The overall number of years of teaching experience ranged from 0 to 42 years, with a mean of about 15 years. Most of the participants (80\%) had an undergraduate degree $(63 \%)$ or a graduate degree (15\%), while $22 \%$ had only a seminary education. Background data about the school were collected at a meeting with the school principals. A meeting with the teachers in each school was held to explain to them about their participation in the study and to describe the research goals to them in general terms. The teachers then filled out questionnaires, which were collected immediately afterwards. Thus the completion rate of the questionnaires was close to $100 \%$.

\subsection{OCB Questionnaire}

To measure teacher OCB, the scale developed by Somech and Drach-Zahavy to examine OCB in Israeli schools [21] was used. The questionnaire consists of 23 statements which address the three dimensions of OCB. It includes eight items on OCB to the students, for example,
"I stay in class during breaks in order to listen to my students," eight items on OCB to the school, for example, "I tend to spend my time in the care for and decoration of the school," and seven items on OCB to the teachers, for example, "I tend to help new teachers even when this is not part of my role definition." A five point Likert-type scale ranging from 1 =totally disagree to 5 =totally agree was used. The internal validity of the questionnaire was measured by the factor analysis which converged to a result very similar to that of the literature and indicated three dimensions of OCB. The reliability level was excellent and even higher than in the literature: OCB to students $-\alpha=0.802$, OCB to teaching staff $-\alpha=0.84$, and OCB to school $-\alpha=0.94$.

\subsection{Commitment to the Organization Questionnaire}

To measure affective commitment to the organization, the eight item scale of Allen and Meyer was used [27]. This questionnaire includes 8 items that examine the worker's affective attachment to the organization, his identification with and his involvement in it. In this study, the word 'organization' was changed to the word 'school.' For example, 'I would be very happy to spend the rest of my career with this school'. A 5 point Likert-type scale ranging from 1 =totally disagree to $5=$ totally agree was used to measure this attitude.

To measure the value congruence commitment of the teacher, the five item scale of O'Reilly and Chatman [28] was used. Their questionnaire examines the internalization or involvement of the teacher predicated on the congruence between the individual and organizational values. In this study, the word 'organization' was changed to 'school.' For example, 'Since joining this school, my personal values and the school's values have become more similar'. A 5 point Likert-type scale ranging from $1=$ totally disagree to $5=$ totally agree was used.

The internal validity of the questionnaire was measured by a factor analysis with Varimax rotation that showed that the two factors are identical to those of the literature in only three iterations, when $59 \%$ of the explained variance was obtained. The factor of affective commitment explains $31 \%$ of the variance, while the factor of value congruence commitment explains $29 \%$ of the variance. The load of the items on each one of the factors was about 0.40 . The reliability was $\alpha=0.86$ for affective commitment and $\alpha=0.89$ for value congruence commitment.

\subsection{Survey of Perceived Organizational Support (SPOS)}

The variable of POS was examined using the shortened version of the survey of POS composed by Eisenberger, Cumming, Armeli, and Lynch [36]. It consists of an eight item scale to evaluate the degree to which workers perceive the organization as appreciating their contribution and seeing their welfare. In this study, the word 'organization' was changed to 'school.' For example, 'My school really cares about my well-being'. A 5 point Likert-type scale ranging from $1=$ totally disagree to $5=$ totally agree was used. The internal validity of the questionnaire was measured by a factor analysis with 
Varimax rotation that showed that all eight items of the questionnaire converged into only one factor while explaining $60.2 \%$ of the explained variance. The load of all the items on the factor was above 0.67, and the reliability was $\alpha=0.90$.

\subsection{Teacher Job Satisfaction Questionnaire}

The variable of job satisfaction was examined using the eight item scale of Gaziel, Borgler, and Nir [37]. The respondents were asked to note the degree to which they are satisfied with each item, for example, "The social relations with the people I work with.”

A 5 point Likert-type scale ranging from 1 =very not satisfied to 5=very satisfied was used. The internal validity of the questionnaire was measured by a factor analysis with Varimax rotation that showed that all eight items converged into only one factor, while explaining $61 \%$ of the explained variance. The load of all the items on the factor was above 0.69 and the reliability was $\alpha=0.90$.

It should be noted that the demographic variables of the school and the teachers were controlled in the order of the different calculations.

\section{Results}

The means and standard deviations of the variables of attitudes and OCB are presented in Table 1. The internal correlations among the variables of the attitudes (Table 2) and among the variables of organizational citizenship behavior (Table 3) were examined using Pearson correlations.
Table 1. Means and Standard Deviations of Teacher Attitudes and Teacher OCB in the Entire Sample

\begin{tabular}{cccccc}
\hline & N & MIN & MAX & M & SD \\
Affective Commitment & 313 & 1.75 & 5.00 & 3.87 & .76 \\
Value Congruence Commitment & 311 & 1.30 & 5.00 & 3.53 & .90 \\
Perceived Organizational Support & 313 & 1.50 & 5.00 & 3.86 & .70 \\
Job Satisfaction & 310 & 2.25 & 5.00 & 4.18 & .63 \\
OCB Teachers & 314 & 1.00 & 5.00 & 4.01 & .72 \\
OCB Students & 314 & 1.38 & 5.00 & 2.99 & .72 \\
OCB Organization & 314 & 1.25 & 5.00 & 3.53 & .99 \\
\hline
\end{tabular}

As Table 1 shows, the range of scores of teacher attitudes and teacher OCB is very broad (with the exception of the variable of satisfaction, for which the range is narrower). The means of the variables indicate high attitudes (attitudes that range from 3.53 to 4.18) and moderate OCB (2.99 to the students) and high OCB (3.53 to the organization).

The differences between the two dimensions of commitment (affective commitment and value congruence commitment) and the three dimensions of OCB were examined using $t$ tests for dependent samples. The findings show that there is a significant difference between the two dimensions of commitment $(t)(1,310)$ $=8.97, \mathrm{p}<.001$ ), when the means indicate that affective commitment is significantly higher than value congruence commitment (3.87 and 3.53, respectively). Significant differences were found in the dimensions of OCB, in the following order: OCB towards teachers was the highest $(\mathrm{M}=4.01)$ and was different significantly from OCB to the organization $(\mathrm{t}(1,313)=12.79, \mathrm{p}<.001)$ and from OCB to students $(\mathrm{t}(1,313)=28.86, \mathrm{p}<.001)$. The second dimension is OCB to the organization $(\mathrm{M}=3.53)$, which was significantly different from OCB to the students, which was found to be the lowest $(M=2.99)(t \quad(1,313)=13.90$, $\mathrm{p}<.001)$.

Table 2. Pearson Correlations for the Examination of the Internal Correlations among the Four Attitudes Indices

\begin{tabular}{cccc}
\hline & Affective Commitment & Value Congruence Commitment & Perceived Organizational Support \\
\hline Affective Commitment & - & & Satisfaction \\
Value Congruence Commitment & $.67^{* * *}$ & - & - \\
Perceived Organization Support & $.71^{* * *}$ & $.67^{* * *}$ & $.67^{* * *}$ \\
Job Satisfaction & $.65^{* * *}$ & $.62^{* * *}$ & - \\
\hline$* * * \mathrm{p}<.001$ & &
\end{tabular}

Table 3. Pearson Correlations for Examination of the Internal Correlations among the Three OCB Indices

\begin{tabular}{cccc}
\hline & $\begin{array}{c}\text { OCB } \\
\text { Teachers }\end{array}$ & $\begin{array}{c}\text { OCB } \\
\text { Students }\end{array}$ & $\begin{array}{c}\text { OCB } \\
\text { Organization }\end{array}$ \\
\hline OCB Teachers & - & & \\
OCB Students & $.63^{* * *}$ & - & \\
$\begin{array}{c}\text { OCB } \\
\text { Organization }\end{array}$ & $.75^{* * *}$ & $.72^{* * *}$ & - \\
\hline$* * * \mathrm{p}<.001$ & &
\end{tabular}

As can be seen in Table 2, significant positive correlations were found between the four variables of attitudes. These correlations indicate that, in general, teachers who expressed high affective commitment also expressed high value congruence commitment, high perceived organizational support, and high satisfaction. Teachers who expressed lower attitudes tended to do so in all four indices.

As can be seen in Table 3, an examination of the correlations among the indices of the OCB indicates significant positive correlations among the indices themselves. According to these correlations, a teacher who reported high OCB did so in all three of the dimensions together. Alternatively, a teacher who reported low OCB tended to do so in all three indices.

Table 4. Pearson Correlations between Teacher Attitudes and Teacher OCB

\begin{tabular}{|c|c|c|c|}
\hline & \multicolumn{3}{|c|}{ OCB Indices } \\
\hline & Teachers & Students & Organization \\
\hline Affective Commitment & $.62 * *$ & $.51^{* *}$ & $.66^{* *}$ \\
\hline Value Congruence Commitment & $.68 * *$ & $.65 * *$ & $68 * *$ \\
\hline Perceived Organizational Support & $.50 * *$ & $.49 * *$ & $.52 * *$ \\
\hline Job Satisfaction & $54 * *$ & $.47^{* *}$ & $.59 * *$ \\
\hline
\end{tabular}

${ }^{*} \mathrm{p}<.01 * * \mathrm{p}<.001$

As can be seen in Table 4, there are strong positive correlations between teacher attitudes and teacher OCB.
These significant correlations, indicate that teachers who have high attitudes, namely a high level of commitment to 
the organization, who have high POS, and who have a high level of satisfaction also expressed high OCB to the students, the teachers, and the organization. The reverse was also true. It should be noted that although all the correlations were strong and significant, the correlation between teacher attitudes and the OCB to students is lower than the correlations between teacher attitudes and the OCB to teachers and to the organization. Thus, for instance, while the correlations between the teachers' affective commitment and the OCB to teachers and to the organization are $r=.66$ and $r=.62$, the correlation between the teachers' attitudes and the OCB to students is $r=.51$.

A multiple regression analysis was performed to measure the incremental contribution of each of the four attitudes to the three OCB dimensions. Table 5 presents these results.

Table 5. Linear Multiple Regression for the Prediction of the OCB Indices by the Attitudes Variables

\begin{tabular}{|c|c|c|c|}
\hline \multicolumn{4}{|c|}{ OCB Indices } \\
\hline & $\begin{array}{l}\text { Teachers } \\
\text { Beta }\end{array}$ & $\begin{array}{l}\text { Students } \\
\text { Beta }\end{array}$ & $\begin{array}{c}\text { Organization } \\
\text { Beta }\end{array}$ \\
\hline Affective Commitment & $31 * * *$ & .10 & $.35 * * *$ \\
\hline $\begin{array}{l}\text { Value Congruence } \\
\text { Commitment }\end{array}$ & $.49 * * *$ & $.52 * * *$ & $.43 * * *$ \\
\hline $\begin{array}{c}\text { Perceived } \\
\text { Organizational Support }\end{array}$ & $.14^{*}$ & .08 & $.15^{*}$ \\
\hline Job Satisfaction & $.13^{*}$ & .02 & $.20 * * *$ \\
\hline $\mathrm{F}(\mathrm{p})$ & $85.12 * * *$ & $57.85 * * *$ & $97.96 * * *$ \\
\hline $\mathrm{R}^{2}$ & $53 \%$ & $43 \%$ & $56 \%$ \\
\hline
\end{tabular}

From the above table it is clear that Value Congruence Commitment has the highest contribution to all three dimensions of OCB. For OCB to teachers and to the organization, Affective Commitment, Perceived Organizational Support and Job Satisfaction have been found to contribute significantly. However as opposed to these two dimensions of OCB, the OCB to students significantly related only to Value Congruence Commitment. The other three attitude variables were not found to be significantly related to OCB to students.

\section{Discussion}

The first part of the discussion will focus on the findings on OCB as a multidimensional concept, while the second part will focus on the findings related to the four variables of teacher attitudes and their correlations with OCB. In this study, OCB was found to be a multidimensional variable, as was the case in previous studies of organizations and schools [for instance, [19,38]]. It is comprised of three dimensions identical to those reported in earlier studies conducted on teachers in Israel [16,20,21]: teacher, student and organization. The results show that OCB to teachers is the highest, then OCB to the school, and OCB to the students is the lowest. Although it could be expected that teachers would invest most of their time in promoting their students, the results can be explained in two ways. First, according to the social exchange theory, workers will display OCB as a reward to the organization and its management in return for the support and help they receive from the organization [39]. It is possible that teachers, like other workers, prefer to do volunteer activities in school, since these are more visible and directed at people who can reward them. A teacher who displays OCB to the school or to colleagues (for instance, helping the principal/teachers) believes he has a greater chance of being seen and rewarded. In contrast, OCB to the students is not only less public but is also directed at a young population that cannot offer them any reward.

Another way to explain the high level of OCB to teachers and the organization is to consider the changes in the educational system that have led to a broader perspective of the teaching profession [40]. Unlike in the past, when the teacher's role was limited to teaching in class, today the teacher belongs to a community of teachers and to an organization, works in collaboration and has many organizational roles besides teaching. Teachers understand that these additional areas are an integral part of their job and participate in them above and beyond their duty. The teachers maintain that their contribution to school and to their colleagues is very meaningful today, and therefore they prefer to show these dimensions of OCB.

As for the relationship between teacher attitudes and OCB, the study found a strong relationship between all the teacher attitudes and OCB in general, as predicted by the four hypotheses. These results are similar to previous studies among teachers, which found OCB to be influenced by some of the attitude variables: job satisfaction and commitment of teachers to the organization $[8,16,38]$. The study also found a significant correlation between POS and the OCB of teachers, a correlation that was hardly examined in the past. The more the teachers felt their school supported them, the higher their OCB was. Research [42] has found that workers perceive the organization and their superiors as one unit, and as such, the school principal is the one who is responsible for creating a supportive atmosphere that can encourage and increase the OCB of his teaching staff.

Of all the attitude variables, the strongest impact on the teachers' behavior is the commitment that derives from the congruence between the teacher's values and school's values. In contrast, the influence of job satisfaction is weaker. This finding is interesting in light of previous studies that noted that job satisfaction is the most meaningful variable that leads to workers' OCB [12]. The present results illustrate the difference between the teaching profession and other sectors [43]. Teaching is considered a 'moral' and 'ideological' profession that incorporates values and ideals; people who choose teaching are motivated by a sense of mission and a moral commitment to society. Therefore, it is likely that for teachers, the sense of congruence between their values and the values of the schools most significantly influences their OCB. This specific type of commitment to the organization was not examined in previous studies conducted on teachers.

As was noted, the correlation between the teachers' attitudes and their OCB to the students is not as strong as the correlation between teachers' attitudes and their OCB to the teachers and to the organization. Similarly, the regression analysis found that three out of the four attitude variables that were studied did not influence the OCB to students. In other words, the study shows that teachers' attitudes have a greater influence on their OCB to the school and its teachers than on their OCB to their students. The teacher's behavior to the student is less influenced by 
his attitudes, and is quite stable. This result could be explained by the teachers' perception of their role as one of mainly promoting and assisting their students [43]. Their behavior to the students is not influenced by their positive or negative attitudes to the school.

\section{Conclusions}

This study provides a better understanding of the concept of OCB among teachers, its dimensions, and the attitudes that influence it. The insights from the study lead to recommendations for principals and shapers of educational policy as well as to suggestions for future research.

First, this study found that teacher OCB includes three different dimensions, each of which is influenced by different variables. It is recommended to continue studying OCB according to its different dimensions.

The research found that teachers display a lower level of OCB to students. This finding is of concern, and it is recommended to encourage teachers to increase these behaviors to students, who are the main focus of teaching. This could be done if the school encouraged and gave positive feedback to teachers who showed OCB to students, Principals who would specifically praise teachers with a high level of OCB to students could motivate teachers to continue these behaviors and others to adopt them.

The study shows that teacher attitudes have an influence on most dimensions of OCB. One implication of this result is that in order to increase OCB in schools, it is necessary for teachers to develop positive attitudes. Principals should be aware of the fact that OCB is primarily undertaken by teachers because of reciprocity norms. When principals display sensitivity to teachers and show support, understanding, and empathy for their needs, they are likely to influence teacher' attitudes, which will cause teachers to respond with reciprocity and thus may increase their expressions of OCB.

The results also show that the teacher's commitment to the organization, deriving from the congruence between the teacher's values and the school's values, was the most significant variable and the only one that influenced all dimensions of OCB. To encourage the teachers' sense of commitment, it is recommended that the principal have discussions with them about their values and those of the school and develop a common educational vision that the teachers can identify with. This way, schools can benefit from an increase in teachers' OCB.

It should be noted that this study has several limitations. First, there are limitations of the instruments. The information regarding the teachers' expressions of behavior and attitudes was based on questionnaires for self-completion. It is possible that data collected in this way are subject to errors that derive from self-bias, from the respondent's lack of objectivity. Future research can combine additional methods for the collection of data on the teachers' OCB. The second limitation pertains to the generalizability of the findings. The research was performed in elementary schools in the center of Israel. Similar studies should be done in other educational organizations such as high schools, public and private educational institutions, teacher education colleges and universities [43]. In addition, it is recommended to perform a follow up study in other countries and sectors [45]. Finally, the research addresses a limited number of variables that may be related to teacher OCB. Future studies could focus on more variables related to the teacher, the principal, and the school [46]. The discovery of additional variables will shed further light on the understanding of OCB, which is a significant variable, and on ways to increase it among teachers.

\section{References}

[1] Buszin, J. S., "Beyond school finance: refocusing education reform litigation to realize the deferred dream of education equality and adequacy,” Emory Law Journal, 62.6, 1613-1657. 2013.

[2] Ben-David, D. “A macro look at Israeli economy and society”, Policy Paper Number 1, Taub Center. 2010

[3] Burns, R. W. and DiPaola, M. F. “A study of organizational justice, organizational citizenship behavior, and student achievement in high schools," American Secondary Education. 42 (1), 4-23. Fall. 2013.

[4] DiPaola, M. and Tschannen-Moran, M. "Organizational citizenship behavior in school and its relationship to school climate," Journal of School Leadership, 11, 424-447. 2001.

[5] Organ, D. W., Podsakoff, P. M., and MacKenzie, S. B. Organizational citizenship behavior: its nature, antecedents, and consequences. Sage Publications, Thousand Oaks, CA. 2006.

[6] Dunlop, P. D. and Kibeom, L. "Workplace deviance, organizational citizenship behavior, and business unit performance: the bad apples do spoil the whole barrel," Journal of Organizational Behavior, 25, 67-80. 2004.

[7] DiPaola, M. and Hoy, W. "Organizational citizenship of faculty and achievement of high school students," The High School Journal, 88 (3), 35-44. 2005a.

[8] Cohen, A. "One nation, many cultures," Cross Cultural Research, 41 (3), 273. August. 2007.

[9] Paillé, P. "Citizenship in the workplace: examining work attitudes as predictors among French employees,” International Journal of Business and Management, 5.4., 53-64. April. 2010.

[10] Jimmieson, N. L., Hannam, R. L., and Yeo, G. B. "Teacher organizational citizenship behaviours and job efficacy: implications for student quality of school life," British Journal of Psychology, 101.3, 453. Aug. 2010.

[11] Bateman, T. S. and Organ, D. W. "Job satisfaction and the good soldier: the relationship between affect and employee citizenship," Academy of Management Journal, 26, 587-595. 1983.

[12] Smith, C. A., Organ, D. W. and Near, J. P. "Organizational citizenship behavior: its nature and antecedents," Journal of Applied Psychology, 68, 653-663. 1983.

[13] Organ, D. W. Organizational citizenship behavior: the good soldier syndrome, Lexington Books, Lexington, MA. 1988.

[14] Podsakoff, P. M. and MacKenzie, S. B. "Impact of organizational citizenship behaviors on organizational performance: a review and suggestions for future research,” Human Performance, 10 (2), 133-151. 1997.

[15] DiPaola, M. and Hoy, W. "School characteristics that foster organizational citizenship behavior,” Journal of School Leadership, 15, 308-326. 2005b.

[16] Bogler, R. and Somech, A. "Organizational citizenship behavior in school how does it relate to participation in decision making?," Journal of Educational Administration, 43(5), 420-438. 2005.

[17] Van Dyne, L., Cummings, L. L., and McLean Parks, J. "Extra-role behaviors: in pursuit of construct and definitional clarity," Research in Organizational Behavior, 17, 215-285. 1995.

[18] Christ, O., Van Dick, R., and Wagner, U. "When teachers go the extra mile: foci of organizational identification as determinants of different forms of organizational citizenship behavior among schoolteachers,” British Journal of Educational Psychology, 73, 329-341. 2003.

[19] Podsakoff, P. M., MacKenzie S. B., Paine, J. B., and Bacharach, D. G. "Organizational citizenship behavior: a critical review of the theoretical and empirical literature and suggestion for future research,” Journal of Management, 26, 513-563. 2000. 
[20] Somech, A. and Bogler, R. "Antecedents and consequences of teachers organizational and professional commitment," Educational Administration Quarterly, 38, 4, 555-557. 2002.

[21] Somech, A. and Drach-Zahavy, A. "Understanding extra-role behavior in schools: the relationships between job satisfaction, sense of efficacy, and teachers' extra-role behavior," Teaching and Teacher Education, 16, 649-659. 2000.

[22] Dikshit, A. Y. and Dikshit, P. "A study of corporate entrepreneurship development by incorporating high performance HRM practices: investigating the mediating role of OCB and procedural justice at workplace," International Journal of Management Research and Reviews, 4.2, 221-230. Feb. 2014.

[23] Eisenberger, R., Huntington, R., Hutchison, S., and Sowa, D. "Perceived organizational support," Journal of Applied Psychology, 71, 500-507. 1986.

[24] Gouldner, A.W. "The norm of reciprocity,” American Sociological Review, 25, 161-178. 1960.

[25] Flynn, F. J. "How much should I give and how often? The effects of generosity and frequency of favor exchange on social status and productivity," The Academy of Management Journal, 46, 539-553. 2003.

[26] Bozeman, D. P. and Perrewe, P. L. "The effect of item content overlap on Organizational Commitment Questionnaire-turnover cognitions relationship," Journal of Applied Psychology, 86, 161173. 2001.

[27] Allen, N. J. and Meyer, J. P. "The measurement and antecedents of affective, continuance and normative commitment to the organization,” Journal of Occupational Psychology, 63, 1-18. 1990.

[28] O'Reilly, C. A. and Chatman, J. "Organizational commitment and psychological attachment: the effects of compliance, identification and internalization on prosocial behavior," Journal of Applied Psychology, 71, 492-499. 1986.

[29] Wallace, J. E. "Becker's side-bet theory of commitment revisited: is it time for a moratorium or resurrection?" Human Relation, 50, 727-749. 1997.

[30] Meyer, J. P., Stanley, D. J., Hersocovitch, L., and Topolnysky, L. "Affective, continuance, and normative commitment to the organization: a meta-analysis of antecedents, correlates, and consequences," Journal of Vocational Behavior, 61, 20-52. 2002.

[31] Sesen, H. and Basim, N. H. "Impact of satisfaction and commitment on teachers' organizational citizenship,” Educational Psychology, 32.4, 475-491. 2012.

[32] Johlke, M. C., Stamper, C. L. and Shoemaker, M. E. "Antecedents to boundary spanner perceived organizational support," Journal of Managerial Psychology, 17, 116-128. 2002.

[33] Maslow, A. H. Motivation and Personality. Harper, NY. 1954.
[34] Vroom, V. H. "Educating managers for decision making and leadership," Management Decision, 41, 968-978. 2003.

[35] Bragger, J. D., Rodriguez-Srednicki, O., Kutcher, E. J., Indovino, L. and Rosner, E. "Work-family conflict, work-family culture, and organizational citizenship behavior among teachers," Journal of Business and Psychology, 20 (2), 303-324. 2005.

[36] Eisenberger, R., Cummings, J., Armeli, S., and Lynch, P. "Perceived organizational support, discretionary treatment, and job satisfaction," Journal of Applied Psychology, 82, 812-820. 1997.

[37] Gaziel, H., Borgler, R., and Nir, A. The implementation of school based management in schools: an assessment of inhibitors and catalysts, Research report submitted to the Chief Scientist Office, The Ministry of Education. 2005.

[38] Cohen, A. The relationship between multiple commitments and organizational citizenship behavior in Arab and Jewish culture, University of Haifa. 2006.

[39] Feather, N. T. and Rauter, K. A. "Organizational citizenship behavior in relation to job status, job insecurity, organizational commitment, identification job satisfaction and work values," Journal of Occupational and Organizational Psychology, 77, 8194. 2004.

[40] Clement, M. and Vandenberghe, R. "Teachers' professional development: a solitary or collegial (ad)venture?," Teacher and Teaching Education, 16, 81-101. 2000.

[41] Motowidlo, S. J. "Some basic issues related to contextual performance and organizational citizenship behavior in human resource management," Human Resource Management Review, 10 (1), 11-126. 2000.

[42] Rhoades, L. and Eisenberger, R. "Perceived organizational support: a review of the literature," Journal of Applied Psychology, 87 (4), 698-714. 2002.

[43] Oplatka, I. "Going beyond role expectations: toward an understanding of the determinants and components of teacher organizational citizenship behavior," Educational Administration Quarterly, 42 (3), 385-423. 2006.

[44] Chompookum, D. and Brooklyn, C. D. "The effect of internal career orientations on organizational citizenship behavior in Thailand," Career Development International, 9, 406-423. 2004.

[45] Tierney, P., Farmer, S. M. and Graen, G. B. "An examination of leadership and employee creativity: the relevance of traits and relationships," Personnel Psychology, 52, 591-620. 1999.

[46] Somech, A. and Ron, I. "Promoting organizational citizenship behavior in schools: the impact of individual and organizational characteristics," Educational Administration Quarterly, 43 (1), February, 38-66. 2007. 